\title{
Dangerous reactions to treatment of onchocerciasis with diethylcarbamazine
}

\author{
A D M BRYCESON, D A WARRELL, HELEN M POPE
}

British Medical fournal, 1977, 1, 742-744

\section{Summary}

Nine Nigerians with severe onchocerciasis who were treated with diethylcarbamazine developed clinical changes, ranging in severity from mild itching to distress, cough, and syncope. Physiological changes (fever, tachypnoea, tachycardia, or hypotension) were seen in eight. In five patients the systolic blood pressure fell by more than $25 \mathrm{~mm} \mathrm{Hg}$, and one patient collapsed on attempting to sit up. Circulating eosinophils decreased profoundly in all cases, reaching their lowest levels just before or during the clinical and physiological changes. A fall in serum complement (C3) accompanied the reaction but there was no fall in antibody titre.

Diethylcarbamazine probably acts on the parasite's cuticle, thus exposing it to the body's defence mechanisms. The reaction coincides with the death of microfilariae, and the accompanying physiological changes may be so severe, even in generally healthy patients, that treatment should preferably be started in hospital.

\section{Introduction}

Diethylcarbamazine, which is widely used in the treatment of onchocerciasis, is cheap, readily available, and effective against microfilariae. In the usual dose of $10 \mathrm{mg} / \mathrm{kg}$ body weight/day it is rapidly excreted and not toxic. The well-known reaction to treatment consists of itching skin and eyes, increase in rash, aggravation of keratitis and iritis, tender lymph node enlargement, arthralgia, and fever. ${ }^{1}$ There is histological, ${ }^{2}{ }^{3}$ electronmicroscopical, ${ }^{4}$ and haematological ${ }^{5}$ evidence that this is an anaphylactic reaction to antigens released by dying microfilariae. The reaction may be fatal: in Oomen's group of 327 patients treated with diethylcarbamazine there were 27 deaths, seven of them attributable to treatment. ${ }^{6}$ These seven patients, six of whom were debilitated by malnutrition or tuberculosis, became shocked, lapsed into coma, and died within a few days of starting treatment. None, however, showed the expected early features of a reaction to the drug. Six of the 15 patients treated by Fugelsang and Anderson ${ }^{7}$ became acutely breathless; one of them collapsed and another became unconscious.

We studied the physiology and immunology of the reaction to treatment in onchocerciasis to understand better its pathogenesis and hazards.

\section{Patients and methods}

Nine Nigerian men in danger of blindness from untreated severe onchocerciasis were admitted to Ahmadu Bello University Hospital,

Department of Medicine, Ahmadu Bello University, Zaria, Nigeria A D M BRYCESON, MD, DTM\&H, senior lecturer (present address: Hospital for Tropical Diseases, London NW 1 OPE)

D A WARRELL, DM, MRCP, senior lecturer (present address: Radcliffe Infirmary, Oxford OXE 6HE)

HELEN M POPE, senior technologist
Zaria. All came from Kudaru, a village in the northern Nigerian savanna ${ }^{*}$ where onchocerciasis is highly endemic.

Skin snips from shoulder and buttock were weighed and teased in normal saline. After 15 minutes microfilariae were counted. During the studies the patients lay supine in bed. Electrocardiograms and rectal, shoulder, and trunk skin temperatures were recorded continuously, and pulse and respiratory rates and blood pressure were frequently recorded. In three particularly severe cases (cases 1, 2, and 9) intra-arterial and central venous pressures were measured through fine percutaneous catheters in the brachial artery and superior vena cava. When recorded variables had stabilised for one to three hours diethylcarbamazine $100 \mathrm{mg}$ was given by mouth. The patients were observed for the next eight to 20 hours and blood was sampled every 15-60 minutes.

Total and differential white blood cell counts were measured conventionally. Eosinophils were counted directly in Discombe's fluid using the opposite side of the same Neubauer chamber: neutrophil counts were obtained by subtraction. The accuracy of this simple and rapid method was checked by conventional differential counts in the first two studies.

Immediate hypersensitivity to onchocercal antigens was tested by intradermal injection of $20 \mathrm{mg}$ of protein-rich antigen prepared from adult Onchocerca volvulus worms ${ }^{9}$ and sterilised by membrane filtration. The differences in the diameter of the weal immediately after skin testing and 15 minutes later were recorded. There was no response in uninfected controls. In cases 1 and 2 skin tests were also performed every hour after treatment with diethylcarbamazine. Antibody titres to onchocercal antigens were measured by indirect haemagglutination ${ }^{9}$ and complement (C3) by radial diffusion ${ }^{11}$ using commercial antiserum (Hyland Laboratories) and a Zaria standard of pooled normal sera.

\section{Results}

Values before treatment are shown in table I. All patients had onchocercal keratitis and severe iritis, two had early cataracts, and one had choroiditis. There was no relation between symptoms, physical findings, microfilarial density, immediate hypersensitivity, antibody titre, or eosinophilia, but in the one patient with pachyderma only one microfilaria was found in eight skin snips.

The reactions to treatment are shown in tables II and III. The four components of the reaction-clinical, physiological, haematological, and immunological-did not necessarily coexist in the same patient.

Clinical changes were noted in all patients. They began half an hour to 12 hours after the dose of diethylcarbamazine and continued for minutes, hours, or days. The changes included intensification of symptoms (itching of skin and eyes, eye pain, photophobia, lacrimation), local inflammation (conjunctival and cutaneous oedema), and systemic disturbances (chills, restlessness, sweating, cough, and syncope).

Physiological changes included fever, tachycardia, hypotension, and tachypnoea. Eight of the nine patients showed one or more of these features. Skin temperature increased by $3.2 \pm 0.7^{\circ} \mathrm{C}$ (range $2 \cdot 3-3 \cdot 9^{\circ} \mathrm{C}$ ) on the shoulder and by $2 \cdot 8 \pm 1 \cdot 4^{\circ} \mathrm{C}$ (range $0 \cdot 7-4 \cdot 4^{\circ} \mathrm{C}$ ) on the trunk. Hypotension, defined as a fall in systolic blood pressure of over $25 \mathrm{~mm} \mathrm{Hg}$ compared with the pretreatment value, was observed in five patients, and was severe in cases 2 and 9. One patient (case 9) collapsed after sitting up in bed, and his systolic pressure remained below $80 \mathrm{~mm} \mathrm{Hg}$ for the next three hours. Hypotension usually accompanied or closely followed the peak of fever, but was also observed in one patient (case 3) who remained afebrile. Severe hypotension was recorded in two of the three patients with severe clinical reaction. There was no other correlation between the severity of clinical and physiological changes.

Haematological changes-Circulating eosinophils diminished profoundly in all patients and disappeared completely in two (table II). Eosinophils started to disappear about the time that clinical and physiological changes began and reached their lowest level two to 
TABLE I-Pretreatment observations in nine men with onchocerciasis

\begin{tabular}{|c|c|c|c|c|c|c|c|c|c|c|c|c|c|}
\hline \multirow{2}{*}{$\begin{array}{l}\text { Case } \\
\text { No }\end{array}$} & \multirow{2}{*}{$\underset{\text { (years) }}{\text { Age }}$} & \multirow{2}{*}{$\begin{array}{l}\text { Nutritional } \\
\text { state }\end{array}$} & \multirow{2}{*}{ Itching } & \multicolumn{4}{|c|}{ Skin signs } & \multirow{2}{*}{$\begin{array}{l}\text { Lymph } \\
\text { nodes }\end{array}$} & \multicolumn{2}{|c|}{$\begin{array}{c}\text { Microfilariae } \\
\text { (per mg skin) }\end{array}$} & \multirow{2}{*}{$\mid \begin{array}{c}\text { Blood } \\
\text { eosinophils } \\
\left(\times 10^{9} / 1\right)\end{array}$} & \multirow{2}{*}{$\begin{array}{l}\text { Skin } \\
\text { test }+ \\
(\mathrm{mm})\end{array}$} & \multirow{2}{*}{$\underset{\text { titre }}{\text { Haemagglutination }}$} \\
\hline & & & & $\begin{array}{l}\text { Papular } \\
\text { urticaria }\end{array}$ & Pachyderma & Atrophy & Depigmentation & & Shoulder & Buttock & & & \\
\hline $\begin{array}{l}1 \\
2 \\
3 \\
4 \\
5 \\
6 \\
7 \\
8 \\
9\end{array}$ & $\begin{array}{l}25 \\
35 \\
40 \\
50 \\
50 \\
23 \\
23 \\
30 \\
18\end{array}$ & $\begin{array}{l}\text { Good } \\
\text { Fair } \\
\text { Fair } \\
\text { Poor } \\
\text { Good } \\
\text { Good } \\
\text { Good } \\
\text { Good } \\
\text { Good }\end{array}$ & $\begin{array}{l}\text { Severe } \\
\text { Slight } \\
\text { Slight } \\
\text { Severe } \\
\text { Severe } \\
\text { Slight } \\
\text { Slight } \\
\text { Slight } \\
\text { Slight }\end{array}$ & $\begin{array}{l}+ \\
- \\
- \\
- \\
- \\
= \\
- \\
-\end{array}$ & $\begin{array}{l}+ \\
- \\
- \\
- \\
- \\
- \\
= \\
-\end{array}$ & $\begin{array}{l}- \\
+ \\
\overline{+} \\
+ \\
+ \\
- \\
\overline{+} \\
+\end{array}$ & $\begin{array}{l}+ \\
+ \\
+ \\
+ \\
- \\
- \\
+ \\
-\end{array}$ & $\begin{array}{l}++ \\
- \\
- \\
+ \\
+ \\
+ \\
+ \\
+\end{array}$ & $\begin{array}{c}1 \\
425 \\
70 \\
220 \\
20 \\
1 \\
\text { Positive* } \\
200 \\
16\end{array}$ & $\begin{array}{c}0 \\
650 \\
300 \\
115 \\
20 \\
67 \\
\text { Positive* } \\
440 \\
100\end{array}$ & $\begin{array}{l}3.5 \\
2.5 \\
1.7 \\
2.5 \\
0.75 \\
1.0 \\
1.7 \\
2.4 \\
3.5\end{array}$ & $\begin{array}{r}13 \\
13 \\
\text { ND } \\
9 \\
10 \\
N D \\
\text { ND } \\
6 \\
9\end{array}$ & $\begin{array}{l}13 \\
12 \\
18 \\
17 \\
15 \\
17 \\
23 \\
20 \\
13\end{array}$ \\
\hline
\end{tabular}

${ }^{*}$ Positive but not enumerated. + Value is increase in mean diameter of weal at 15 minutes. $¥$ Indirect haemagglutination titre expressed as reciprocal log ${ }_{2}$. ND $=$ Not done.

TABLE II-Features of reaction after treatment with diethylcarbamazine in nine patients

\begin{tabular}{|c|c|c|c|c|c|c|c|c|}
\hline \multirow{2}{*}{$\begin{array}{l}\text { Case } \\
\text { No }\end{array}$} & \multirow{2}{*}{$\begin{array}{c}\text { Clinical changes in severity and } \\
\text { nature of reaction }\end{array}$} & \multicolumn{4}{|c|}{ Physiological changes* } & \multicolumn{3}{|c|}{$\begin{array}{l}\text { Haematological changes: in circulating } \\
\text { leucocytes }\end{array}$} \\
\hline & & $\begin{array}{l}\text { Increase in } \\
\text { rectal } \\
\text { temperature } \\
(\mathrm{C})\end{array}$ & $\begin{array}{l}\text { Increase in } \\
\text { pulse rate } \\
\text { (beats } / \mathrm{min} \text { ) }\end{array}$ & $\begin{array}{l}\text { Decrease in } \\
\text { systolic blood } \\
\text { pressure } \\
(\mathrm{mm} \mathrm{Hg})\end{array}$ & $\begin{array}{l}\text { Increase in } \\
\text { respiratory } \\
\text { rate } \\
\text { (breaths } / \mathrm{min} \text { ) }\end{array}$ & $\begin{array}{l}\text { Eosinophil } \\
\text { change } \\
\left(\times 10^{9} / 1\right. \\
(\text { and } 0.0))\end{array}$ & $\begin{array}{c}\text { Lymphocyte } \\
\text { change } \\
\left(\times 10^{8} / 1\right. \\
\left.\left(\text { and }{ }_{0}\right)\right)\end{array}$ & $\begin{array}{l}\text { Neutrophil } \\
\text { change } \\
\left(\times 10^{9} / 1\right. \\
(\text { and } \%))\end{array}$ \\
\hline 1 & $\begin{array}{l}\text { Moderate: chill at } 5 ! \mathrm{h} \text {, scratching } \\
\text { at } 5\end{array}$ & \multirow{2}{*}{$2 \cdot 7$} & \multirow{2}{*}{40} & \multirow{2}{*}{16} & \multirow{2}{*}{18} & \multirow{2}{*}{$-1 \cdot 7(-15)$} & \multirow{2}{*}{$-0 \cdot \varepsilon(-89)$} & \multirow{2}{*}{ Nil } \\
\hline 2 & $\begin{array}{l}\text { Severe: itching eyes and skin, } \\
\text { cough, sweating at } 50 \mathrm{~min} \text {, skin }\end{array}$ & & & & & & & \\
\hline 3 & $\begin{array}{l}\text { oedema, corneal clouding at } 1 ! \mathrm{h} \\
\text { Moderate: scratching at } 2 ! \mathrm{h}\end{array}$ & $\begin{array}{l}1 \cdot 2 \\
0 \cdot 1\end{array}$ & $\begin{array}{l}34 \\
12\end{array}$ & $\begin{array}{l}58 \\
40\end{array}$ & $\begin{array}{l}6 \\
9\end{array}$ & $\begin{array}{l}-2.5(-100) \\
-1.55(-91)\end{array}$ & $\begin{array}{l}-1 \cdot 7(-85) \\
-1.05(-51)\end{array}$ & $\begin{array}{l}+2.0(+83) \\
-0.4(-51)\end{array}$ \\
\hline 4 & $\begin{array}{l}\text { Very mild: eyes itching at } 23 \mathrm{~h} \text {, } \\
\text { no skin itching or changes }\end{array}$ & $2 \cdot 1$ & & & & $-2.45(-08)$ & $-1.9(-68)$ & $+3 \cdot 8(+146)$ \\
\hline 5 & Very mild: itching at $30 \mathrm{~min}$ & $0 \cdot 8$ & 20 & 14 & 3 & $-0 \cdot 6(-80)$ & Nil & $\stackrel{+}{\mathrm{Nil}}$ \\
\hline \multirow{3}{*}{$\begin{array}{l}7 \\
8 \\
9\end{array}$} & \multirow{3}{*}{$\begin{array}{l}\text { crying at } 45 \mathrm{~min} \\
\text { Moderate: itching at } 11^{3} \mathrm{~h} \\
\text { Moderate: itching } 1 ! \mathrm{h} \\
\text { Severe: itching at } 45 \mathrm{~min} \text {, sweating } \\
\text { at } 6 \mathrm{~h} \text {, syncope at } 6 \mathrm{~h}\end{array}$} & $1 \cdot 1$ & 25 & 17 & 6 & $-1 \cdot 0(-100)$ & Nil & $+1 \cdot 0(+38)$ \\
\hline & & $\begin{array}{l}2.9 \\
1.8\end{array}$ & 49 & 30 & 10 & $\begin{array}{l}-1.65(-97) \\
-2.55(-98)\end{array}$ & $\begin{array}{l}-1 \cdot 3(-93) \\
-1.3(-54)\end{array}$ & $+7 \cdot 8(+650)$ \\
\hline & & & & 56 & 9 & $-3.4(-97)$ & $-0.7(-63)$ & $+1 \cdot 8(+72)$ \\
\hline $\begin{array}{l}\text { Mean value } \\
(: 1 \mathrm{SI}))\end{array}$ & & $1.6: 0.9$ & $31: 12$ & $32: 17$ & $10: 5$ & & & \\
\hline
\end{tabular}

*Maximum changes observed within $20 \mathrm{~h}$ of treatment.

TABLE III-Absolute values of physiological variables and timing of maximum changes after treatment in nine patients

\begin{tabular}{|c|c|c|c|c|}
\hline & \multicolumn{2}{|c|}{ Peak absolute value } & \multicolumn{2}{|c|}{ Time after treatment $(h)$} \\
\hline & Mean $1 \mathrm{SD}$ & Range & Mean: $1 \mathrm{SD}$ & Range \\
\hline $\begin{array}{l}\text { Rectal temperature (C) } \\
\text { Pulse rate (beats min).. } \\
\text { Minimum systolic }\end{array}$ & $\begin{array}{rl}38 \cdot 1 & 0 \cdot 9 \\
105 & : 21\end{array}$ & $\begin{array}{c}36 \cdot 3-39 \cdot 4 \\
70-145\end{array}$ & 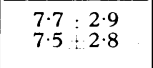 & $\begin{array}{l}2 \cdot 3-11 \cdot 8 \\
3 \cdot 0-11 \cdot 8\end{array}$ \\
\hline $\begin{array}{l}\text { pressure }(\mathrm{mm} \mathrm{Hg}) \ldots \\
\text { Respiratory rate }\end{array}$ & $78: 15$ & $44-100$ & $7 \cdot 7: 3 \cdot 8$ & $3 \cdot 5-14 \cdot 8$ \\
\hline (breaths min) & $27: 7$ & $18-36$ & $7 \cdot 2: 2 \cdot 4$ & $3 \cdot 5-11 \cdot 8$ \\
\hline
\end{tabular}

nine hours later. There was an accompanying fall in circulating lymphocytes and monocytes, and subsequent neutrophil leucocytosis. The day after treatment eosinophil counts had nearly regained their previous level, but the neutrophil leucocytosis persisted.

Immunological changes-Circulating antibody titres, estimated by indirect haemagglutination, did not change by more than one doubling dilution during the reaction. Immediate cutaneous hypersensitivity was transiently depressed in cases 1 and 2 during the reaction. Skin weal diameters decreased from $13 \mathrm{~mm}$ and $12 \mathrm{~mm}$ at zero time to respective minima of $2 \mathrm{~mm}$ and $6 \mathrm{~mm}$, one hour and six hours after treatment. These increased to $12 \mathrm{~mm}$ and $8 \mathrm{~mm}$ at six hours and nine hours. C3 levels fell sharply from pretreatment levels of 100$120^{\circ}$, of a normal mean value to $40-92^{\circ}{ }^{\circ}$ during the first eight hours after treatment. In one patient values remained low at $40-45 \%$ of normal for a further two days.

\section{Discussion}

Clinical and haematological evidence of a reaction to treatment with diethylcarbamazine was found in all nine of these patients with onchocerciasis, and physiological changes were detected in eight.
Diethylcarbamazine does not kill microfilariae in vitro, ${ }^{11}$ but recent ultrastructural studies suggest that the drug may expose them to the body's defence mechanisms by an action on the parasite's cuticle. ${ }^{4}$ Diethylcarbamazine flushes microfilariae from the dermis into the blood, urine, sputum, and aqueous humour within two hours of treatment, ${ }^{12-14}$ and into the epidermis, where microabscesses form around them. ${ }^{3}$ The reaction coincides with the mobilisation and death of microfilariae. The absence of rigors before the rise in temperature suggests that there is no sudden release of endotoxin, as there is in the Jarisch-Herxheimer reaction of louse-borne relapsing fever. ${ }^{15}$ The cutaneous and conjunctival oedema suggest an increase in vascular permeability. The maximum rise in skin temperature usually preceded the hypotensive phase, which suggested that vasodilatation was a contributing factor, as in other reactions to treatment. ${ }^{16}{ }^{17}$ Immediate hypersensitivity and reaginic antibodies are well-known findings in onchocerciasis. ${ }^{1819}$ The transient depression of cutaneous anaphylaxis observed in two patients might indicate either a transient consumption of circulating anaphylactic antibody, or, more probably, temporary total degranulation of cutaneous mast cells. Anaphylactic inflammation occurring in the lungs in response to the sudden arrival of microfilariae may explain the acute respiratory symptoms. ${ }^{\text {? }}$

A decrease in circulating eosinophils is the most consistent and sensitive indicator of the reaction. ${ }^{20}$ Eosinophils are attracted to products of mast cell degranulation, ${ }^{21}$ and, together with histiocytes, cluster round degenerate microfilariae after diethylcarbamazine treatment. ${ }^{3}$. Perhaps enzymes from these cells penetrate the microfilarial cuticle that has been damaged by diethylcarbamazine and kill the organism. As the anaphylactic reaction takes place predominantly in tissues, the blood eosinopenia probably reflects an acute demand for eosinophils. The clinical and physiological reactions are usually preceded by 
eosinopenia, suggesting that they may result from a failure of eosinophil supply to keep pace with demand. None of Oomen's fatal cases developed the classical clinical reaction to treatment and only $36 \%$ showed blood eosinophilia before treatment compared with $68 \%$ of the rest. ${ }^{6}$ Perhaps the reaction, dependent on eosinophils, in some way protects the patient against parasite "toxins."

The fall in serum C3 levels suggests that antibodies other than reaginic antibodies play a part in the reaction. IgG and $\operatorname{IgE}$ will bind to heat-killed microfilariae in vitro, but complement binding could not be shown ( $\mathrm{K}$ Schillhorn van Veen and A D M Bryceson, unpublished). Electron-dense deposits that resemble immune complexes appear on the surface of damaged microfilariae. ${ }^{4}$ Complement fixation by immune complexes might lead to vascular damage and increased permeability, aggravating and prolonging the effects of the anaphylactic reaction. Classical features of Arthus-type cutaneous vasculitis have not, however, been observed. Possible pathogenic mechanisms of the reaction are shown in the figure.

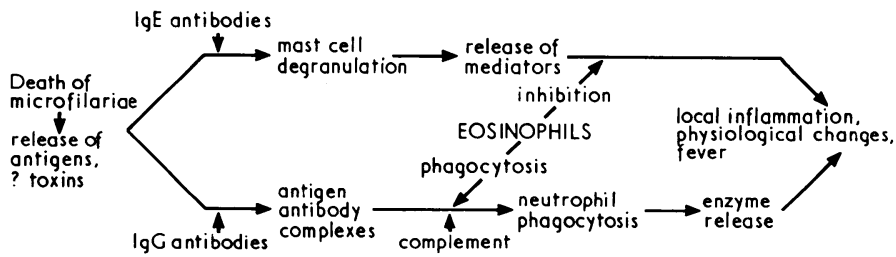

Possible mechanisms underlying reaction to treatment with diethylcarbamazine in onchocerciasis.

Our observations, together with those of Fuglsang and Anderson, ${ }^{7}{ }^{13}$ indicate that the treatment of onchocerciasis with diethylcarbamazine is potentially dangerous, even in generally healthy patients. Since individual susceptibility cannot be predicted, all patients should ideally start treatment in hospital or at least lie down for 48 hours. Not all microfilariae are quickly killed, ${ }^{3}$ and the reaction may continue for several days if diethylcarbamazine is continued. Severe hypotension should be treated by laying the patient flat and by giving intravenous fluids, but these measures achieved only temporary improvement in
Oomen's cases. Antihistamines are not effective in controlling the reaction ${ }^{14}$ or in suppressing the skin test response. Systemic corticosteroids are not always effective in preventing ${ }^{13}$ or controlling $^{6}$ the reaction, but $40 \mathrm{mg}$ of intramuscular methylprednisolone relieved symptoms when given after the reaction had developed. ${ }^{14}$ Topical corticosteroids rapidly controlled ocular inflammation.

This work was carried out with support from the Medical Research Council (UK) and the Wellcome Trust.

Requests for reprints should be addressed to Dr A D M Bryceson, Hospital for Tropical Diseases, 4 St Pancras Way, London NW1 0PE.

\section{References}

${ }^{1}$ Mazzotti, L, Revista del Instituto de Salubridad y Enfermedades Tropicales, 1948, 9, 235.

2 Hawking, F, British Medical fournal, 1952, 1, 992.

3 Connor, D H, et al, Human Pathology, 1970, 1, 553.

4 Gibson, D W, et al, American fournal of Tropical Medicine and Hygiene, $1976,25,74$.

5 Oomen, A P, Studies on Onchocerciasis and Elephantiasis in Ethiopia. Haarlem, De Erven F Bohn V, 1969.

${ }^{6}$ Oomen, A P, Transactions of the Royal Society of Tropical Medicine and Hygiene, 1969, 63, 548.

7 Fuglsang, H, and Anderson, J, Transactions of the Royal Society of Tropical Medicine and Hygiene, 1974, 68, 72.

${ }^{8}$ Crosskey, R W, and Crosskey, M E, Annals of Tropical Medicine and Parasitology, 1959, 53, 10.

- Bryceson, A D M, et al, Clinical and Experimental Immunology, 1976, 24, 168.

${ }^{10}$ Fahey, J L, and McElvey, E M, fournal of Immunology, 1965, 94, 84.

${ }^{11}$ Hawking, F, Sewell, P, and Thurston, J P, British fournal of Pharmacology, 1950, 5, 217.

12 Buck, A A, Onchocerciasis. Geneva, World Health Organisation, 1973.

13 Fuglsang, H, and Anderson J, fournal of Helminthology, 1974, 48, 93.

14 Fazen, L E, et al, American fournal of Tropical Medicine and Hygiene, 1976, $25,250$.

15 Bryceson, A D M, et al, Clinical Science, 1972, 43, 343.

16 Warrell, D A, et al, Clinical Science, 1970, 39, 123.

17 Warrell, D A, et al, American fournal of Medicine, 1971, 51, 176.

18 Bozicevich, J, et al, American fournal of Tropical Medicine, 1947, 27, 51.

19 Ulrich, M, Pinardi, M E, and Convit, J, Transactions of the Royal Society of Tropical Medicine and Hygiene, 1970, 64, 111.

${ }^{20}$ Money, G L, Fournal of Tropical Medicine and Hygiene, 1960, 63, 238.

21 Goetzl, E J, Wasserman, S I, and Austen, K F, Progress in Immunology II, $1974,4,41$.

(Accepted 12 fanuary 1977)

\title{
Metergoline in the inhibition of puerperal lactation
}

\author{
GIUSEPPE DELITALA, ANTONIO MASALA, SERGIO ALAGNA, LUISA DEVILLA, \\ GIUSEPPE LODICO, GAETANO LOTTI
}

British Medical fournal, 1977, 1, 744-746

\section{Summary}

Seventy-eight mothers who did not want to breast-feed their newborn infants took part in a trial to assess whether

\footnotetext{
Cattedra di Semeiotica Medica 2a, University of Sassari, 07100 Sassari, Italy

G DELITALA, MD, senior assistant

A MASALA, MD, contrattista

S ALAGNA, MD, borsista

L DEVILLA, MD, borsista

G LOTTI, MD, professor of medicine

Clinica Ostetrica e Ginecologia, University of Sassari, 07100 Sassari, Italy

G LODICO, MD, assistant
}

metergoline could effectively suppress puerperal lactation. Metergoline $8 \mathrm{mg} /$ day was given to 69 women within 24 hours after delivery and continued for five days to prevent lactation. The remaining nine women were given a course of metergoline once lactation had started. The drug was effective in both preventing and suppressing lactation. Milk secretion, engorgement, and pain were significantly reduced in women taking metergoline. Metergoline has a similar effect to bromocriptine in suppressing lactation, but its mechanism of action remains unknown.

\section{Introduction}

There have been several attempts recently to inhibit puerpera' lactation. Methods have included hormonal inhibition with oestrogens alone or in combination with androgens, and 